\title{
Analysis of Urban Heritage Management in the Heritage Area of Jakarta Old-City
}

\author{
Diah Putri Utami \\ Departement of Public Administration, Faculty of \\ Administrative Sciences, Universitas Indonesia \\ Depok, Indonesia \\ E-mail: diah.putri31@ui.ac.id
}

\author{
Mohammad Riduansyah Anza \\ Departement of Public Administration, Faculty of \\ Administrative Sciences, Universitas Indonesia \\ Depok, Indonesia \\ E-mail: moh.riduansyah@ui.ac.id
}

\begin{abstract}
The Jakarta Old-City Area is a geographical spatial unit that has been appointed as an urban heritage of Jakarta. This study discusses the application of urban heritage management in Jakarta Old-City Area. This is related to the fact that Jakarta Old-City Area is used for many activities, including conservation activities as a heritage area, so its management becomes crucial to notice. This study uses a post-positivist approach in which the theory of urban heritage management becomes the analytical basis of research findings. The data were obtained from in-depth interviews, observation, and literature study. The result of the study shows that heritage management in Jakarta Old-City Area has not been optimal since the regulation system, community engagement, technical and financial managements are not integrated and still contain problems in each dimension. In the case of regulatory systems, the absence of regulations that specifically regulate the management of the area becomes the most important issue. Meanwhile, the lack of community empowerment, not based on community needs and characteristics, becomes a problem in terms of community engagement. For technical management, the control of the TSP and TACB to determine the outcome of efforts to maintain the value and characteristics of the Jakarta Old City as a heritage area is still not strong; in addition, the financial management, in terms of the existing financing alternatives, has not yet accommodated the local economy and the management activities of the area itself.
\end{abstract}

Keywords-urban heritage; urban heritage management; Jakarta Old-City Area

\section{Introduction}

According to [18], development is referred to as series of efforts to pursue growth and change towards modernity in a planned and conscious manner. In the context of urban development, one thing associated with modernity is the urban heritage, as stated by Françoise Choay, 1992 (in [1]), "...heritage is finally associated with modernity". Massive urban development can encourage the development and alteration of functions of urban spaces, including changes in urban spatial functions that are part of the municipal history [3].

One of the changes in the urban environment that needs attention is the change in cultural objects in the form of urban objects of heritage. This is because basically heritage is not only a record of the past - it is an integral part of the current and future urban identity [5]. United Nations Educational Scientific and Cultural Organization as in [19] also sees urban heritage as important for a city both now and in the future. Urban heritage, both tangible and intangible, is a source of social cohesion, a factor of diversity and a driver of creativity, innovation, and urban regeneration.

Although considered important, the existence of the object and the area of heritage in a city is often being ignored, even also damaged, destroyed, or lost. UNESCO [20] argues that the world's heritage is in jeopardy due to armed conflict and war, earthquakes and other natural disasters, pollution, individual hunting, uncontrolled urbanization and uncontrolled tourism development. In addition, exponential urban growth may also threaten the sustainability of the historic urban landscape as in [1]. On the basis of these problems, the concept of heritage conservation and management emerges 
whose results are largely determined by the Government as the dominant actor [4].

In Indonesia, the concept of heritage is synonymous with cultural heritage or pusaka. Considering Indonesia is the largest archipelagic country with a rich diversity of natural and cultural resources, and based on Law Number 11 Year 2010 concerning cultural heritage, heritage management efforts are done by the government on objects, buildings, structures, sites and areas. The data from Pantau Pusaka Indonesia show that Indonesia still has a susceptible condition of heritage, among others land use; vulnerable condition; poor management; ownership disputes; stolen/looted goods; damaged, destroyed, dirty, neglected, dismantled/destroyed, and sold goods [16]. Most susceptible conditions of heritage can be found in Java Island because based on the data from the Ministry of Education and Culture of the Republic of Indonesia [15], Java has the most preserved cultural heritage, while Jakarta is the province with the highest number of cultural objects of heritage, registering up to 28,237 objects [14]. While Bandarin and van Oers assert that Jakarta as one of the mega cities experiences an exponential increase in urbanization and urban growth. This is a challenge for the Jakarta Provincial Government to manage their objects of heritage.

Based on the Spatial Plan of Jakarta 2011-2030, there are four locations that become the areas of building and historical objects restoration in Jakarta. They are the Jakarta Old City Area, Menteng Area, Kebayoran Baru Area, and House of the Pitung. Compared to the four, the Jakarta Old City Area received more attention from the Provincial Government of Jakarta because it is the strategic area of sociocultural interest that has high historical value and is a reflection of historical stories, lifestyles, culture, and civilization of Jakarta's society in the past. The Jakarta Old City Area has also been designated as a cultural heritage area. At a higher level, the Jakarta Old City Area has been proposed and included in a tentative list of UNESCO World Heritage. The Jakarta Old City Area is also mentioned in the Mid-Term Development Plan of Jakarta 2013-2017 as part of the urban community's cultural development mission. Further explanation of it can be found in the Government Work Plan of Jakarta in 2017 where the arrangement of the Jakarta Old City Area became a development priority of West Jakarta Municipal Administration region considering the potential of the area. To manage it, the Provincial Government of Jakarta established Area Management Unit (UPK) of Kota Tua Jakarta.

Nevertheless, the efforts of the Jakarta Provincial Government to manage the Old City Area are still hampered by various problems. These issues include: first, the less profitable Old City image; Second, lack of supporting facilities in the area; Third, the less supportive condition of infrastructure; Fourth, irregular traffic; Fifth, decreasing quality of the surrounding environment (air pollution and river water pollution); Sixth, the not yet integrated policies; Seventh, divided administrative boundaries; and eighth, the defectively targeted institution. In addition, the existing problems are also associated with street vendors with their buying and selling activities around Taman Fatahillah despite having been banned, parked cars and motorcycles, and the behavior of visitors who often throw away the garbage not in its place around the Fatahillah Park as in [13].

The management of Jakarta Old City area is also considered overlapping because there is no clear division of tasks and responsibilities. Cleaning, security, and parking problems often cause a dilemma because there is no synergy between Jakarta Provincial Government, and West Jakarta Municipal Government, and between the administrative village and sub-district [2]. Ary Sulistyo as the representative of $U P K$ Kota Tua Jakarta also revealed that there are obstacles faced by UPK Kota Tua related to its position which is equal to subdistrict. Consequently UPK Kota Tua has 
limited authority to coordinate with other institution which is only limited to security, cleanliness, permit, data collection, and service of information publication. Those problems are seen at the level of management of the Jakarta Old City area; it cannot be separated from the great concept of urban heritage management. Therefore, this paper is expected to provide an overview of urban heritage management in the heritage area of Jakarta Old City.

\section{Theoretical Framework}

Bandarin and van Oers argue that there is a change in the urban heritage management context that is influenced by the emergence of international cityconservation movement. Since the adoption of the last international instrument on the conservation of heritage more than thirty years ago--a UNESCO recommendation on Safeguarding and Contemporary Role of Historic Areas in 1976--the world has witnessed a variety of external and internal changes relevant to the historic city conservation: a) Exponential increase in urbanization on a global scale; b) Growing concern for the environment and the sustainability of urban development; c) The vulnerability of cities in terms of the impact of climate change; d) The changing role of cities, with ongoing market liberalisation, decentralization, and privatisation as new drivers of development; e) The emergence of tourism as one of the largest industries in the world; f) The changing perception of the heritage values of the city to be protected. These six changes overlap and create a complex and dynamic conservation environment with the growth of mutual relationships and the expansion of stakeholder groups, including their competing interests.

At the same time, in many parts of the world the responsibility for action has shifted from the national to the local level, empowering cities and regions to make their own strategies for development. But this increase in tasks and responsibilities at the local level has not always been accompanied by a corresponding increase in capacity, whether institutional, technical or financial. As a result, the market will tend to occupy the resulting vacuum, causing distortions and conflicts. According to Bandarin and van Oers, instead of blaming the market, it seems more appropriate to take a critical look at the ways and means of the practice of conservation, with a view to innovate and update the existing strategies and tools for urban heritage management in order to cope with the increasing complexity and shifting responsibilities.

Bandarin and van Oers also added that the increase in complexity should be balanced by the forging of new partnerships, better institutional coordination, and more available resources, both technical and financial. The successful management of urban heritage demands a robust toolkit. The toolkit for urban heritage management by Bandarin and van Oers should include a range of interdisciplinary and innovative tools, which can be organized into four different categories. It should be emphasized that for urban heritage management to succeed, the policies and actions in these four categories need to be addressed simultaneously, as they are interdependent. These four toolkits are regulatory systems, community engagement tools, technical tools, and financial tools.

\section{Research Method}

This study is a post-positivist research aiming to dig information concerning management of heritage area. This study is also a descriptive research based on its aim and purely based on its benefit, since it is not tied to a research donor or sponsor. Based on the time dimension, this is a cross-sectional study because it is done in one period of time from February to May 2017. This study uses qualitative data collection technique with in-depth interview, observation, and literature study. 
The data obtained in this study were analyzed by coding and analytical strategy of the illustrative method in which urban heritage management theory is illustrated through the management of heritage area of Jakarta Old City.

The parties who become informants in this research are Ary Sulistyo as the staff of the Unit of Service and Information from UPK Kota Tua Jakarta; Nelita as the Head of Administration of Conservation Heritage Center; Jakson Sitorus as the Head of Micro, Small \& Medium Enterprises Sector, Department of Cooperatives, Micro, Small and Medium Enterprises and Trade of DKI Jakarta Province; Zulfikri Alaidrus as the Head of Sub-Division of Area Arrangement, Bureau of City and Environment Arrangement of DKI Jakarta Province; Angie as the Project Administrator from the Consortium of Jakarta Old City; Firman Haris and Dodi as Facilitators of Local Working Group of Jakarta Old City; Ontel and Pencak Silat Community as Local Community of Jakarta Old City; Drs. Yayat Supriatna, MSP as an academician and urban observer; Prof. Dr. Mundardjito as archaeologist and vice chairman of Jakarta Culture Heritage Team, and some visitors and street vendors in the area of Jakarta Old City.

\section{Result and Discussion}

\section{A. Regulatory System}

Regulation is one form of public policy which is manifested in legally and formally codified legislation. In managing urban heritage, the regulatory systems include specific procedures, and actions or decisions that are codified in the form of legislation. The regulatory systems in the Jakarta Old City have been widely stipulated in various laws and regulations. Since 1970s along with the increased attention from the government towards the Jakarta Old City which is considered to have great potential for the city of Jakarta, so many regulations issued at the local level such as the Governor's Decree, Governor's Regulation, and Governor's Instruction. However, all these regulations speak of the preservation, regulation, and development of the area. Until now there is no regulation that specifically regulates the management of the area and how the management is done. Regulation of the area management is just arrived to the legal basis for the establishment of the Area Management Unit of Jakarta Old City (UPK Kota Tua Jakarta).

The current regulation that is used for guiding the management of the area is the Governor's Regulation Number 36 Year 2014 concerning the Jakarta Old City's Master Plan. Its management is mentioned in article 29 and article 30. If further observed, the regulation serves more as government masterplan instead of area management. Two articles in Governor's Regulation Number 36 Year 2014 are not sufficient to accommodate the management of the Jakarta Old City area since they more function as management plan than show how the management should be done. This issue is related to the formation of an authorial body that has not been realized so far; the main cause of which is due to the lack of engineering details (technical details) of the Jakarta Old City's Master Plan.

One thing that needs to be concerned is point (2) of article 29 concerning the establishment of the authorial body in the management of the area. It is a goodwill of the government, since the current area management unit of UPK Kota Tua has limited authority, budget, and Human Resources. However, since the enactment of Governor's Regulation Number 36 Year 2014, the establishment of the authorial body has not been realized so far. This matter is caused by the SKPD having the authority in regulation making: Department of Tourism and Culture of DKI Jakarta. It still heavily refers to the Master Plan of the Jakarta Old City Area. Whereas if we look back, the Jakarta Old City's Master Plan is a grand design that needs technical 
regulations to run it, including in terms of the establishment of an authorial body. The establishment of new institutions requires a thorough assessment and involving the central government; to establish an authorial body of the Jakarta Old City area also requires assessment first. However, when talking about the management of the area, both of the Provincial Government of DKI Jakarta through the Department of Tourism and Culture as well as the central government delegates all technical matters to UPK Kota Tua Jakarta regardless their institutional limitations. This is in contrast to the conservation or utilization of the area where almost all regulations related to the Jakarta Old City area is one regulating the conservation and utilization of the area. There has been a special team authorized to handle the two activities who are more powerful than UPK Kota Tua Jakarta. From here, it appears that the government is more likely to regulate the conservation and utilization of the area than its management.

The regulatory systems in managing heritage area of the Jakarta Old City also appear in the form of Detail Engineering Design as the technical plan for area conservation which has not currently been completed, as well as Strategic Plan or management plan from the owners of buildings in the area. Bandarin and van Oers state that conservation and management technical plans should be seen as a whole and as a valuable part, unless both are harmonized in an integrated way. However, the findings show that the management technical plans in the Jakarta Old City area are not in line with the conservation technical plan. In addition, regulations that administer the area tend to be general regulations. This means not merely for the Jakarta Old City area. The specific regulation on the area can be seen in the form of Term of Reference (TOR) of UPK Kota Tua Jakarta: what is allowed and not allowed in the area as a control mechanism from UPK Kota Tua Jakarta. Uncodified TOR legally causes negative responses from public and private elements in which both stakeholders feel that the current rules are not based on legislation and the details of the provisions are still unclear.

\section{B. Community Engagement}

Community engagement in heritage management is important because it can minimize the occurrence of project defect that targets an urban heritage. The project defect referred here refers to the extent to which the experts dealing with a heritage project understand the important aspects of the community before undertaking the project, including the extent to which the public understand the goals and objectives of the project as a whole. UNESCO [19] adds that along with the increasing perception of joint ownership of heritage or heritage as public goods, the participatory approach in heritage management becomes a crucial one.

In general, people around the Jakarta Old City, especially incorporated in the Local Working Group has been involved in managing the area. It can be seen from the contribution given by the community, especially the local community that is able to manage the information post, maintain the cleanliness and order, along with knowledge and experience owned by the community. These contributions come from the community's own initiatives resulting in a reciprocal relation between the contributions provided and the benefits the community gains and even extends to visitors and other parties in the area such as government and the private sector. The benefits gained as a reciprocal result of the community's contribution are the social benefits from information post and a routine community service to clean up the area; the psychological benefits from sharing historical stories and the preservation of cultural arts; and economic benefits of additional income. The following fig. 1 is the community's contributions in the form of information post management. 


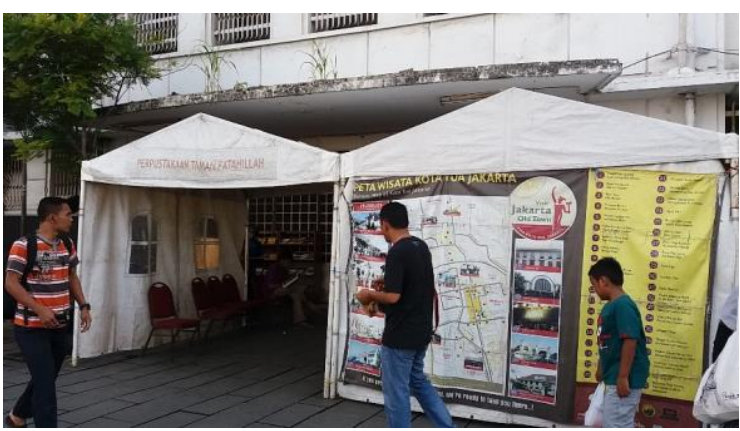

Fig. 1. The LWG-Managed Fatahillah Park Library

Regardless the community's initiative to contribute in managing the area, the government is taking various ways to attract community engagement. Among these are empowerment from central and local governments are: mobilizing participation in government agenda and providing information to the community in the form of socialization, provision of signage, and speakers in the area.

Nevertheless, community engagement has not been optimal. It is because the result of government efforts to attract community engagement still shows a number of problems. First, the target of empowerment has not reached all communities or elements of society and tends to be positive on those who can support the development of tourism in the area. This is because the intercultural dialogue does not include the learning process about people's need and aspirations. Second, the generalization and simplification of the meaning of community engagement is limited to government events and agenda, coupled with public's ignorance of official media information owned by the government. In addition, community engagement is also still in small portions in a number of people. An access for women and disability groups is also not seen and local communities have not been involved in local economic development in the area so that there is distrust from the community to the government's policies in the Jakarta Old City.

\section{Technical Tools}

In managing a heritage, it is important to maintain the original values of the heritage. The process of maintaining these original values involves mostly highly technical procedures and requires specialized knowledge and skills. Therefore, Bandarin and van Oers include technical tools as one of the categories to manage heritage. Technical management of the Jakarta Old City area includes efforts to maintain the authenticity of the architecture and attributes of heritage materials that exist within the area. The effort to maintain the authenticity is done through Tim Sidang Pemugaran and Tim Ahli Cagar Budaya.

According to the Decree of Jakarta Governor Number 1418 Year 2014 concerning Tim Sidang Pemugaran (TSP) and Tim Ahli Cagar Budaya (TACB), TSP and TACB are not under the structure of any Regional Work Unit. Both teams are the team of experts of the governor whose secretariat is in the building of the Conservation Heritage Center. As the name implies, these teams consist of experts in the field of architecture and archeology. Both teams are tasked to escort the process of renovation and conservation of buildings and establish cultural heritage status in DKI Jakarta, including the Jakarta Old City area.

During its implementation, despite the fact that there has been a hearing, the area has been surveyed and has given recommendations as to what must be implemented by the applicant who wants to do the conservation: there are still changes occuring in terms of building materials, facades, and colors that change the characteristics of the area. It is due to the implementation of the recommendation as the result of the hearing process. It is finally returning to the issue of building ownership in the Jakarta Old City area which includes a small portion of government-owned buildings, some belonging to state-owned enterprises, and most are privately owned. For example, from the observation of one of the TSP hearing, there were cases where the applicant violated the agreement that 
had been made by the TSP. The reason is the color difference. The intended color difference occurs in the building on Bank Street as shown below in fig. 2 .

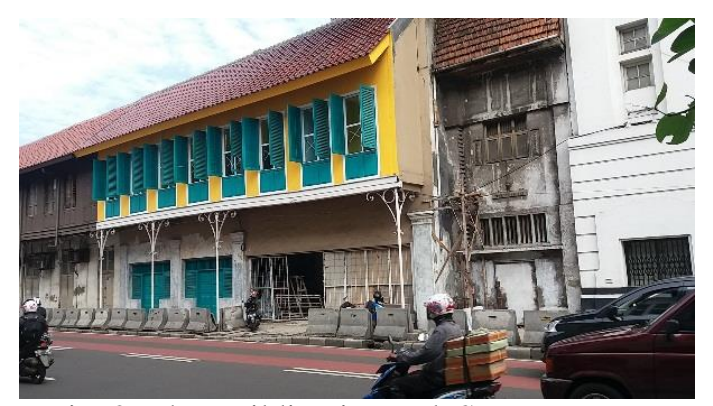

Fig. 2. The Building in Bank Street

Fig. 2 shows how the building on the Bank Street is painted bright green that does not match the characteristics of the Jakarta Old City area. In addition, there is also a case of renovation that begins without a clear permit (the building on Lada Street).

Furthermore, there has been no Environmental Impact Assessment in several projects that have been implemented in the area, especially in the Kali Besar settlement project in zone 2 of the area. Assessment of impacts within the area is limited to one based on the observation from UPK Kota Tua Jakarta and it only includes the physical impact. It has not incorporated the socio-cultural impacts, such as the potential gentrification of the area due to the positive impact of business, attractions and events as well as the negative impact of public crowd. Meanwhile, for the renovation of buildings within the Jakarta Old City area, it also does not have a specific impact assessment, but only an effort to maintain the authenticity of architecture and attributes of building materials conducted through a hearing with TSP. The impact of the utilization of the building after the renovation also does not become the task of the TSP. the utilization of buildings is left entirely to the owner of the building.

Finally, the technical management of heritage area of Jakarta Old City also includes the concept of mixed-use in buildings aimed at sustainability of the area. Although it has been mentioned in the Detailed Regional Spatial Plans and Zoning Plans of Jakarta, its implementation is still in the planning stage. The buildings on the Kerta Niaga block under the process of conservation are those that will later apply the concept of mixed-use in the Jakarta Old City area.

\section{Financial Tools}

The availability of financial sources said by Bandarin and van Oers (2012) can be very helpful in managing heritage. It is due to the existence of financial sources, efforts to maintain heritage values can be done simultaneously with the development of urban areas. The financial sources in Jakarta Old City area are largely derived from the Local Government Budget of DKI Jakarta Province and other flexible financing mechanisms, including incentives, promotion of private investment, micro credit and public private partnership (PPP). The financial resource from Local Government Budget of DKI Jakarta Province which is allocated to $U P K$ Kota Tua and other related institutions can not cover all financing needs in the area so that financing mechanism outside the Local Government Budget is required.

Other financing mechanisms outside Local Government Budget can help the government to manage the area along with its development. However, the budget allocated for the management of the area through UPK Kota Tua Jakarta is more directed to internal programs and activities of the organization. Other financing mechanisms such as incentives, private investment, and PPP are linked to each other. The incentives and PPP are stimulants for private investment into the Jakarta Old City area. However, the impact arising from those mechanisms has not been a particular concern, such as the impact of area gentrification due to the entry of new economies with different characteristics from the local economy. In addition, there is a different local definition 
of the government so that the management and development of the area with local economic bases do not really involve local communities around the area.

From the various things that have been explained, it can be seen that each financial sources has advantages and disadvantages that are summarized in the following table.

TABLE 1.

\begin{tabular}{|c|c|c|}
\hline $\begin{array}{l}\text { Financial } \\
\text { Resources }\end{array}$ & Advantages & Disanvantages \\
\hline \multicolumn{3}{|c|}{ Local Government Budget } \\
\hline $\begin{array}{l}\text { Local } \\
\text { Governmen } \\
\text { t Budget of } \\
\text { DKI } \\
\text { Jakarta } \\
\text { Province }\end{array}$ & $\begin{array}{l}\text { Annual } \\
\text { financial } \\
\text { source to } \\
\text { manage the } \\
\text { area }\end{array}$ & $\begin{array}{l}\text { Budgets are } \\
\text { more allocated } \\
\text { to internal } \\
\text { organization of } \\
\text { UPK Kota Tua } \\
\text { Jakarta }\end{array}$ \\
\hline \multicolumn{3}{|c|}{ Non Local Government Budget } \\
\hline Incentive & $\begin{array}{l}\text { Become a } \\
\text { stimulant to } \\
\text { attract } \\
\text { private } \\
\text { investment } \\
\text { in the area }\end{array}$ & $\begin{array}{l}\text { There is no } \\
\text { specific } \\
\text { provision to } \\
\text { encourage } \\
\text { individuals/pri } \\
\text { vate sector to } \\
\text { develop and } \\
\text { preserve } \\
\text { buildings in the } \\
\text { area }\end{array}$ \\
\hline $\begin{array}{l}\text { Private } \\
\text { Investment }\end{array}$ & $\begin{array}{l}\text { Making the } \\
\text { area alive } \\
\text { and empty } \\
\text { buildings } \\
\text { can be } \\
\text { utilized }\end{array}$ & $\begin{array}{l}\text { Less } \\
\text { investment } \\
\text { involves local } \\
\text { characteristics/ } \\
\text { communities } \\
\text { around the area } \\
\text { as well as } \\
\text { issues of } \\
\text { investment } \\
\text { sustainability }\end{array}$ \\
\hline $\begin{array}{l}\text { Micro } \\
\text { Credit }\end{array}$ & $\begin{array}{l}\text { Facilitate } \\
\text { street } \\
\text { vendors to } \\
\text { develop } \\
\text { their } \\
\text { business }\end{array}$ & $\begin{array}{l}\text { The street } \\
\text { vendors are not } \\
\text { aware of any } \\
\text { microcredit } \\
\text { facilitation } \\
\text { from the } \\
\text { government } \\
\text { and are not } \\
\text { interested in } \\
\text { banking }\end{array}$ \\
\hline
\end{tabular}

\begin{tabular}{|l|l|l|}
\hline & & procedures \\
\hline Public & Being the & Area \\
Private & solution of & gentrification \\
Partnershi & the limited & and lack of \\
p & budget to & social sharing \\
fund assets & \\
that are not & \\
& owned by \\
the & \\
& government \\
in the area \\
and can \\
make the \\
area \\
physically \\
beautiful
\end{tabular}

${ }^{1}$ Summary of Financial Sources in the Jakarta Old City Area

\section{Conclusion}

Urban heritage management in the Jakarta Old City area has not been optimal since the regulatory systems, community engagement, technical management, and managerial finance have not been integrated. In the case of regulatory systems, the absence of regulation that specifically regulates the management of the area becomes the most important issue. Meanwhile, the lack of community empowerment, which is not based on community's needs and characteristics, becomes a problem in terms of community engagement. For technical management, the control from TSP and TACB to determine the outcome of maintaining the value and characteristics of the Jakarta Old City as a heritage area is still not strong. As for the finance of the management, the current financing alternatives have not yet accommodated the local economy and the management activities of the area itself.

\section{References}

[1] Bandarin, F., \& van Oers, R, The Historic Urban Landscape: Managing Heritage in an Urban Century, Oxford: Wiley-Blackwell, 2012.

[2] Berita Satu, "Jadi Destinasi Wisata, Kota Tua Masih Banyak Kekurangan." Retrieved from http://www.beritasatu.com/food-travel/232116- 
jadi-destinasiwisata-kota-tua-masih-banyakkekurangan.html, 2014.

[3] Carmona, M., Tiesdell, S., Taner, O., \& Heath, T, Public Places - Urban Spaces: The Dimension of Urban Design, Oxford: Architectural Press, 2003.

[4] Gilmour, T, Sustaining Heritage: Giving the Past a Future. Sydney: Sydney University Press, 2007.

[5] Global Development Research Center, "Prioritizing Cultural Heritage in the AsiaPacific Region: Role of City Governments." Retrieved from http://www.gdrc.org/heritage/heritagepriority.html, 2015.

[6] Jakarta Provincial Government, APBD Provinsi DKI Jakarta. Retrieved from http://apbd.jakarta.go.id/pub/2017/2/3/giat/list?c $\mathrm{d}=\mathrm{dW}$ 5pdD0xLjE3LjAzMw==, 2017.

[7] Jakarta Provincial Government, Regional Regulation of DKI Jakarta Number 1 Year 2012 concerning Jakarta Spatial Plan 2030, 2011.

[8] Jakarta Provincial Government, Regional Regulation of DKI Jakarta Number 2 Year 2013 concerning Local Government's Medium-term Development Plans of Jakarta 2013-2017, 2013.

[9] Jakarta Provincial Government, Regional Regulation of DKI Jakarta Number 1 Year 2014 concerning the Detailed Regional Spatial Plans and Zoning Plans of Jakarta, 2014.

[10] Jakarta Provincial Government, The Decree of DKI Jakarta Governor Number 36 Year 2014 concerning Master Plan of Jakarta Old City, 2014.
[11] Jakarta Provincial Government, The Decree of DKI Jakarta Governor Number 321 Year 2016 concerning the Establishment, Organization and Working Procedures of the Area Management Unit of Jakarta Old City, 2016.

[12] Jakarta Provincial Government, The Decree of DKI Jakarta Governor Number 121 Year 2016 concerning the Local Government Work Plan, 2017.

[13] Ikatan Peneliti Lingkungan Binaan Indonesia, "Kota Tua Jakarta: Melangkah Menuju Urban Heritage Peringkat Dunia." Retrieved from http://iplbi.or.id/kota-tua-jakarta-melangkahmenuju-urban-heritageperingkat-dunia/, 2015.

[14] Ministry of Education and Culture, Pendaftaran Objek Berdasarkan Provinsi. Retrieved from http://cagarbudaya.kemdikbud.go.id/siteregnas/, 2016.

[15] Ministry of Education and Culture, Peta Penetapan Cagar Budaya. Retrieved from http://cagarbudaya.kemdikbud.go.id/siteregnas/ public/peta, 2016.

[16] Pantau Pusaka Indonesia, Preserved and Endangered Heritage Report. Retrieved from http://heritageinventory.web.id/, 2016.

[17] The Republic of Indonesia, Law Number 11 Year 2010 concerning Cultural Heritage, 2010.

[18] Tjokroamidjojo, B, Pengantar Administrasi Pembangunan. Jakarta: LP3ES, 1974.

[19] United Nations Educational Scientific and Cultural Organization, New Life for Historic Cities. Paris, 2013.

[20] World Heritage Center UNESCO, World Heritage in Danger. Retrieved from http://whc.unesco.org/en/158/, 2016. 